\title{
Registrasi Ulang Bagi Penerima Manfaat Pensiun Yang Berbasis Mobile
}

\author{
Bambang Sukowo *1, Yudo Devianto ${ }^{2}$ \\ ${ }^{1,2}$ Fakultas Ilmu Komputer, Universitas Mercu Buana, Jakarta \\ e-mail: *1'bambang.sukowo@mercubuana.ac.id, ${ }^{2}$ yudo.devianto@mercubuana.ac.id
}

\begin{abstract}
Abstrak
Kegiatan Registrasi Ulang merupakan kegiatan rutin yang bertujuan untuk memastikan bahwa Penerima Manfaat Pensiun apakah masih berhak atas Manfaat Pensiun yang sesuai dengan ketentuan yang berlaku. Selain itu, kegiatan ini juga berguna untuk pengkinian data dari Penerima Manfaat Pensiun. Dalam melakukan Registrasi Ulang, Penerima Manfaat Pensiun diwajibkan mengisi "Formulir Pengesahan Bukti Diri Penerima Manfaat Pensiun" dan wajib ditandasahkan oleh Ketua RT / RW (Ketua Lingkungan Domisili) setempat atau Perwakilan Pensiunan di cabang setempat. Dalam penelitian saat ini akan mencoba untuk membuatkan model atau perancangan suatu aplikasi yang nantinya dapat membantu dalam pelaksanaan kegiatan Registrasi Ulang secara online. Masalah yang ada saat ini adalah belum adanya suatu aplikasi yang dapat membantu melakukan pelaksanaan kegiatan tersebut secara online. Masalah yang dapat di rumuskan pada penelitian ini adalah, bagaimana menghasilkan suatu solusi yang dapat membantu memecahkan permasalahan yang ada saat ini. Dalam menyelesaikan permasalahan yang ada, dibatasi dalam pembuatan model atau perancangan aplikasi yang akan membantu untuk menyelesaikan permasalahan, bilamana ada waktu yang mendukung untuk dibuatkan aplikasi jadi dan sekaligus untuk diimplementasikan, bila tidak akan dilanjutkan pada penelitian selanjutnya.
\end{abstract}

Kata kunci: registrasi ulang, manfaat pensiun, tentang pensiun

\begin{abstract}
Re-registration activities are routine activities that aim to ensure that Pension Beneficiaries are still entitled to Pension Benefits in accordance with applicable regulations. In addition, this activity is also useful for updating data from Pension Beneficiaries. In reregistration, a Pension Beneficiary is required to complete a "Pension Benefit Validation Form" and must be validated by the Head of the local $R T$ / RW (Head of the Domicile Environment) or a Pension Representative at the local branch. In the current research, we will try to make a model or design of an application that can later assist in the implementation of online re-registration activities. The problem that exists today is that there is no application that can help carry out these activities online. The problem that can be formulated in this research is how to produce a solution that can help solve problems that exist today. In solving existing problems, it is limited in making models or designing applications that will help solve the problem, if there is time to support the application to be made and implemented at the same time, if it will not be continued in further research.
\end{abstract}

Keywords: re-registration, retirement benefits, about pensions 


\section{PENDAHULUAN}

$\mathrm{D}$ alam penelitian saat ini akan coba untuk membuatkan model atau perancangan suatu aplikasi yang nantinya dapat membantu dalam pelaksanaan kegiatan Registrasi Ulang secara online. Kegiatan Registrasi Ulang merupakan kegiatan rutin yang bertujuan untuk memastikan bahwa penerima manfaat pension (MP) masih berhak atas MP sesuai dengan ketentuan yang berlaku [1, 2, 3, 4]. Selain itu, kegiatan ini juga berguna untuk pengkinian alamat, nomor telepon dan data lainnya dari Penerima MP. Kegiatan Registrasi Ulang ditujukan kepada seluruh penerima MP yang terdaftar di DANA PENSIUN per akhir tahun sebelumnya dan MP yang bersangkutan masih dibayarkan sampai dengan tanggal dimulainya registrasi ulang (belum hapus). Kegiatan registrasi ulang bagi seluruh penerima MP (Pensiunan Peserta, Janda / Duda / Anak) dilaksanakan sekali dalam 3 (tiga) tahun, sedangkan registrasi ulang khusus yang ditujukan kepada Penerima MP Janda / Duda / Anak dilaksanakan setiap tahun.

Dalam melakukan registrasi ulang, penerima MP diwajibkan mengisi "Formulir Pengesahan bukti diri penerima MP DANA PENSIUN" dan wajib ditandasahkan oleh Ketua RT / RW (Ketua Lingkungan Domisili) setempat atau PPBI Cabang setempat. Bagi penerima MP yang berdomisili di wilayah Jabodetabek, formulir wajib diserahkan langsung ke Kantor DANA PENSIUN. Sedangkan bagi penerima MP yang berdomisili di luar wilayah Jabodetabek, formulir diserahkan melalui PPBI Cabang setempat. Jangka waktu pengembalian formulir tersebut ditentukan oleh DANA PENSIUN lebih kurang selama 3 (tiga) bulan (April s.d. Juni). Setelah jangka waktu tersebut, DANA PENSIUN akan memberikan waktu tambahan selama 3 (tiga) bulan bagi Penerima MP yang belum melakukan registrasi (Juli s.d. September). Apabila dalam jangka waktu 6 (enam) bulan tersebut yang bersangkutan belum melakukan registrasi, maka MP yang bersangkutan akan ditangguhkan sementara oleh DANA PENSIUN pada bulan Oktober hingga bersangkutan melakukan Registrasi Ulang.

Dalam mempersiapkan pelaksanaan kegiatan Registrasi Ulang, DANA PENSIUN harus menyiapkan Sistem Aplikasi Registrasi Ulang dan juga menginformasikan kegiatan ini kepada penerima MP yang harus melakukan Registrasi Ulang. Adapun langkah-langkah persiapan yang dilakukan DANA PENSIUN terlihat pada gambar 1.

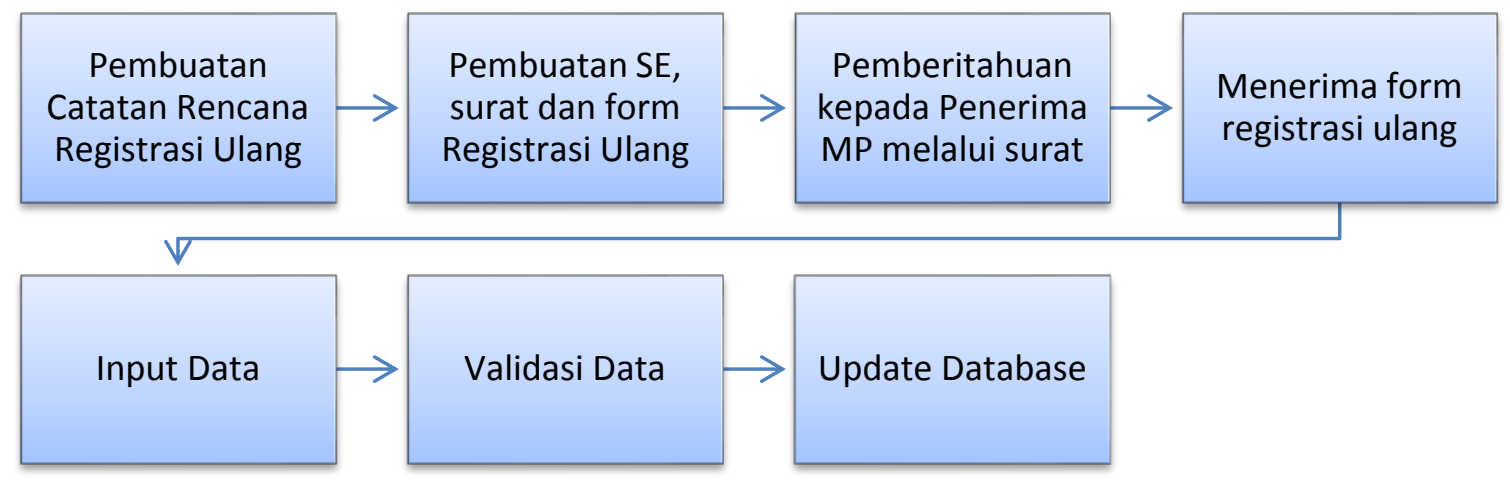

Gambar 1. Bisnis Proses Registrasi Ulang Saat Ini

Pelaksanaan Registrasi Ulang saat ini diawali dengan pembuatan Catatan perihal pelaksanaan Registrasi Ulang untuk memperoleh persetujuan Pengurus. Setelah disetujui, DANA PENSIUN membuat surat edaran, surat pengantar ke PPBI maupun Penerima MP dan Formulir Registrasi Ulang. Tahapan selanjutnya, DANA PENSIUN mengirimkan SE, Surat dan Formulir Registrasi Ulang melalui Pos kepada PPBI Cabang atau masing-masing Penerima MP. Kemudian Penerima MP melakukan Registrasi Ulang dengan cara langsung datang ke DANA PENSIUN maupun melalui PPBI Cabang setempat atau Pos. Setelah formulir Registrasi Ulang 
diterima DANA PENSIUN, maka Pegawai DANA PENSIUN memeriksa kelengkapan formulir tersebut beserta dokumen lainnya untuk kemudian diinput ke dalam Sistem Aplikasi Registrasi Ulang yang telah di buat Tim TI DANA PENSIUN. Data yang telah diinput, akan diperiksa kembali oleh Kepala Seksi untuk kemudian divalidasi. Setelah divalidasi, maka data tersebut tersimpan ke dalam database DANA PENSIUN. Adapun tahapan prosesnya terlihat di gambar 2.

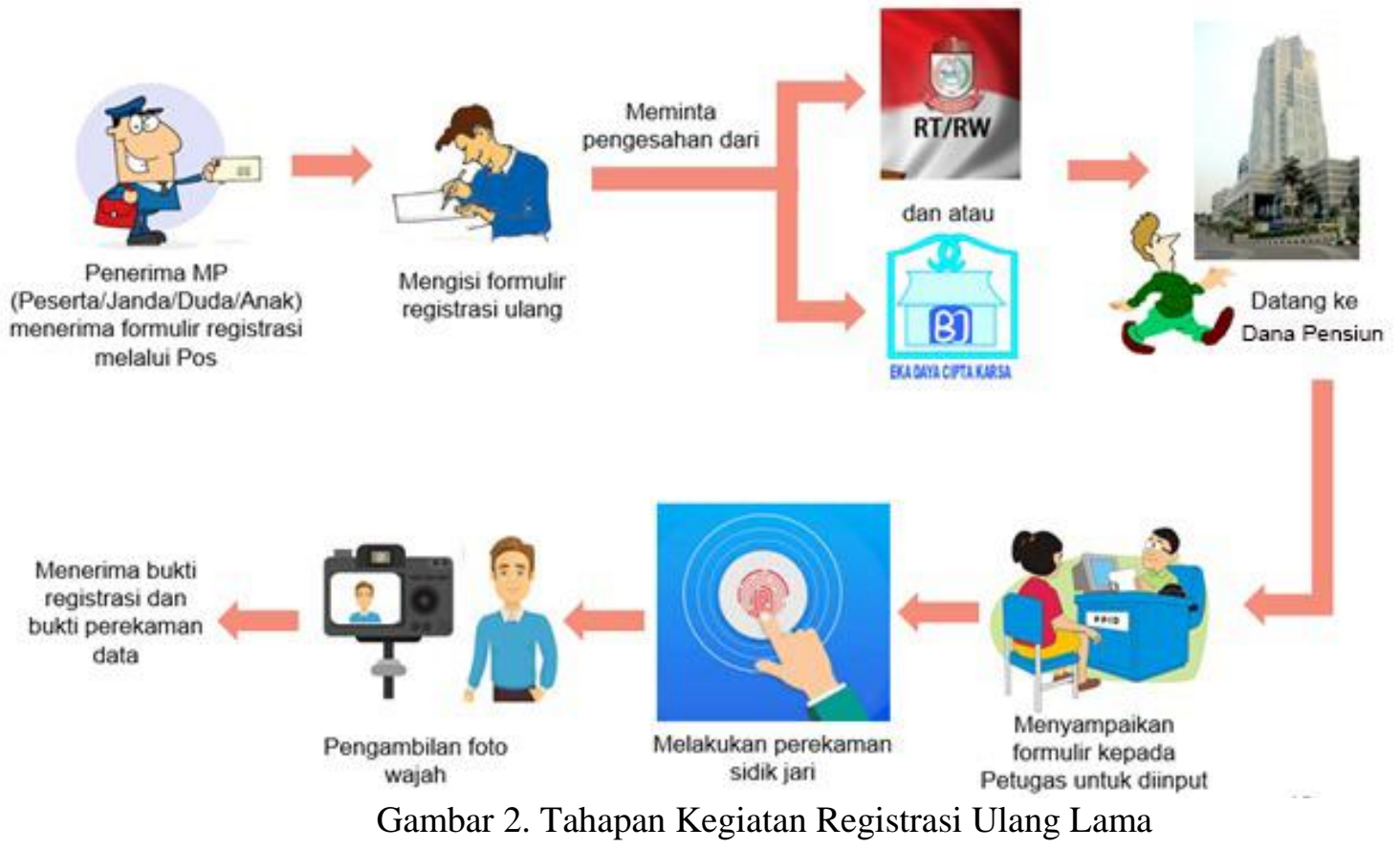

Kegiatan registrasi ulang pada penelitian sebelumnya dapat dilihat pada tabel 1:

Tabel 1. Hasil Penelitian Sebelumnya

\section{No Keterangan}

1 Formulir dikirim melalui via Pos untuk para pensiunan yang berdomisili di luar Jabotabek sedangkan pensiun yang berdomisili di Jabotabek data langsung ke Kantor Dana Pensiun.

2 Penerima MP harus mengisi formulir registrasi ulang kemudian meminta tanda sah dari Ketua RT/RW dan atau Pengurus PPBI Cabang/Korwil/Ketua Rayon.

3 Penerima MP datang ke Dana Pensiun dengan membawa formulir yang telah diisi lengkap beserta dokumen pendukung yaitu fotokopi KTP dan fotokopi KK.

4 Sesampai di Kantor Dana Pensiun, Penerima MP akan mendapat nomor antrian. Setelah nomor antrian disebutkan Petugas, maka Penerima MP datang ke konter Petugas dan menyerahkan formulir beserta dokumen pendukung untuk diinput oleh Petugas. Selanjutnya Petugas mempersilakan Penerima MP untuk berpindah ke tempat perekaman sidik jari dan foto wajah.

5 Penerima MP akan dilayani oleh Petugas dalam melakukan perekaman sidik jari dan foto wajah.

6 Penerima MP akan dilayani oleh Petugas dalam melakukan perekaman sidik jari dan foto wajah 
Aplikasi ini hadir untuk memudahkan dalam penginputan data sebagai pengkinian master pensiun yang di development menggunakan Visual Foxpro dalam bentuk aplikasi desktop dan dikembangkan kembali aplikasi versi Java desktop dengan menambahkan fasilitas Finger Print $[13,18,19]$ dan wajah para pensiunan sebagai penerima Manfaat Pensiun (MP).

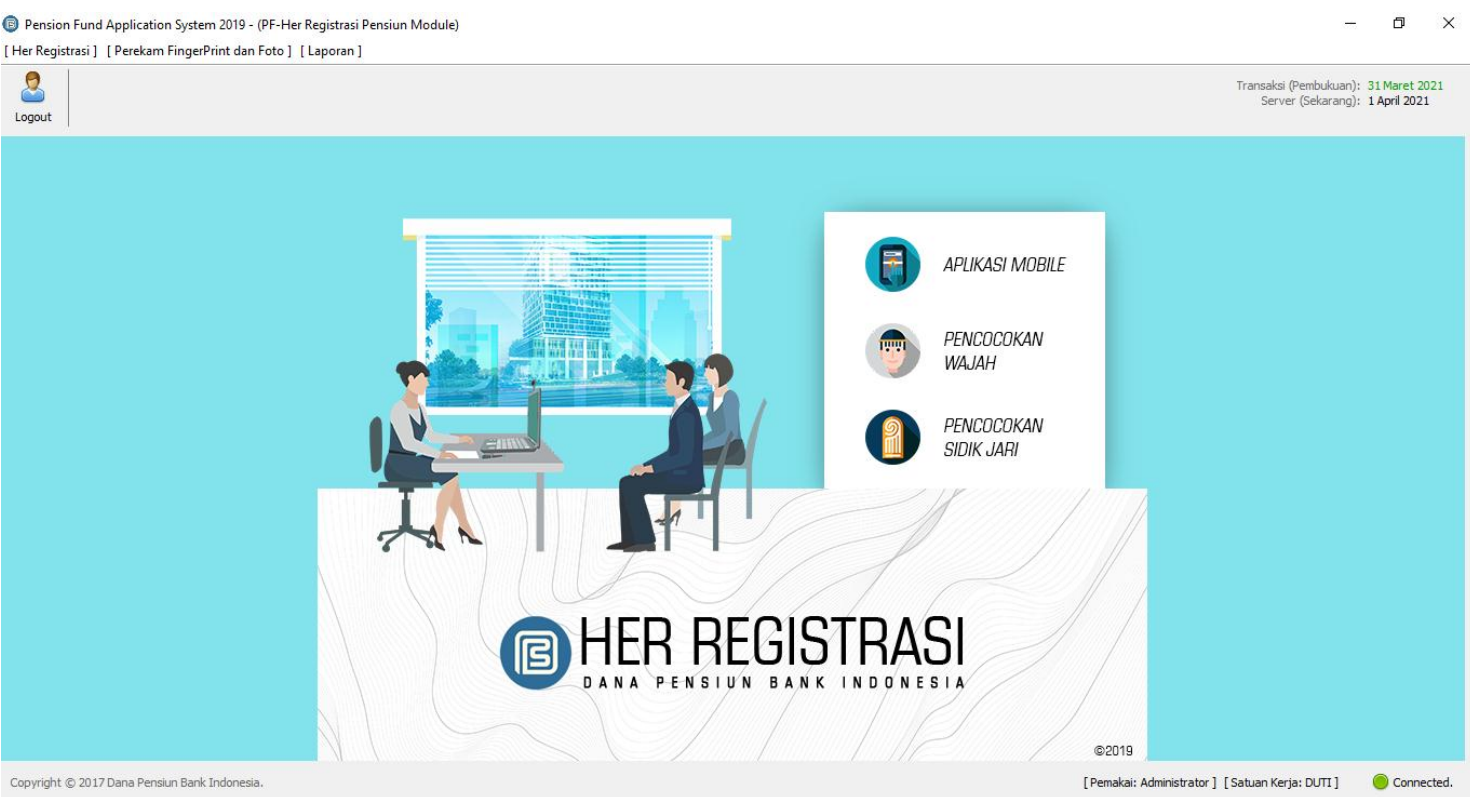

Gambar 3. Her Registasi Versi Desktop

Masalah yang ada saat ini berdasarkan hasil penelitian sebelumnya adalah belum adanya suatu aplikasi yang dapat membantu para pensiunan [11] dalam melakukan Registrasi Ulang secara online.

Masalah yang dapat dirumuskan pada penelitian ini adalah, bagaimana menghasilkan suatu solusi yang dapat membantu memecahkan permasalahan yang ada saat ini.

Dalam menyelesaikan permasalahan yang ada, dibatasi dalam pembuatan model atau perancangan aplikasi yang akan membantu untuk menyelesaikan permasalahan, bilamana waktu yang ada mendukung untuk dibuatkan aplikasi jadi dan sekaligus untuk diimplementasikan, bila tidak akan dilanjutkan pada penelitian selanjutnya.

Manfaat dari penelitian ini diharapkan: 1. Hasil dari model atau perancangan aplikasi ini diharapkan dapat dibuatkan dan diimplementasikan menjadi aplikasi real. 2. Model atau perancangan aplikasi ini dapat digunakan juga oleh Pensiunan yang menerima Manfaat Pensiunan agar dapat melakukan pengkinian data Master Pensiunan.

\section{METODE PENELITIAN}

Jenis penelitian yang kami gunakan adalah penelitian terapan (Applied Research), karena dari hasil penelitian dapat langsung digunakan/diterapkan untuk memecahkan permasalahan yang dihadapi dan pelaksanaan perancangan e-business[5] dengan menggunakan metode information systems development (ISD).

Metode tradisional systems development life cycle (SDLC) memberikan langkahlangkah terstruktur dan formal. Namun metode tersebut perlu diubah untuk menyesuaikan dengan kondisi teknologi informasi dan kebutuhan yang semakin kompleks dan memerlukan flexibility serta responsiveness yang besar. Berbagai metode modern tersedia untuk 
pengembangan sistem yang kompleks atau yang diinginkan cepat terwujud misalkan prototyping, joint application design, object oriented development, dan component-based development [6].

Untuk pengembangan e-business dalam klaster ini, gabungan antara keunggulan SDLC yang terstruktur dan formal, serta prototyping dan component based development akan diterapkan.

Dalam penelitian ini akan dibuat Model atau Perancangan Aplikasi Mobile Apps [9, 10] Registrasi Ulang Penerima Manfaat Pensiun.

Metode pengumpulan data yang digunakan dalam penelitian ini adalah [7, 8]: 1. Metode observasi. Observasi atau pengamatan langsung terhadap obyek penelitian. Teknik observasi dilakukan dengan observasi berstruktur dengan menyiapkan daftar kebutuhan data dan sumber data. 2. Metode studi pustaka. Metode pengumpulan data yang diperoleh dengan mempelajari, meneliti, dan membaca buku, informasi dari internet, jurnal, skripsi, tesis yang berhubungan dengan e-business dan desa.

\section{HASIL DAN PEMBAHASAN}

\subsection{Registrasi Ulang Online Berbasis Web Application}

Registrasi Ulang Online berbasis Web Application adalah sistem registrasi Penerima MP dengan sistem web-based yang memungkinkan proses registrasi ulang tidak terbatas hanya di kantor DANA PENSIUN. Penerima MP dapat diidentifikasi masih hidup atau tidak karena dalam proses registrasi ini terdapat verifikasi berupa autentikasi sidik jari. Selain itu terdapat pembaruan foto terbaru, karena sistem menyediakan fasilitas foto Penerima MP saat registrasi.

Dalam sistem ini, DANA PENSIUN menempatkan perangkat PC/Laptop beserta fingerprint reader, printer dan webcam di beberapa tempat, misalkan kantor DANA PENSIUN dan kantor PPBI Cabang. Perangkat tersebut dioperasikan oleh seorang Admin yang ditunjuk DANA PENSIUN.

Kelebihan sistem web-application ini dibandingkan sistem registrasi yang berjalan saat ini antara lain:

Tabel 2. Kelebihan Sistem Web Application

\begin{tabular}{cll}
\hline No. & Aspek & Keterangan \\
\hline 1. & Aspek Keamanan & $\begin{array}{l}\text { Lebih aman karena ada sisi admin dari DANA PENSIUN yang } \\
\text { dapat memvalidasi user tersebut peserta atau bukan }\end{array}$ \\
\hline 2. & $\begin{array}{l}\text { Aspek } \\
\text { Maintenance }\end{array}$ & $\begin{array}{l}\text { Lebih mudah dikarenakan perangkat keras sudah disesuaikan } \\
\text { dengan kebutuhan standar sistem yang ada di DANA PENSIUN } \\
\text { saat ini }\end{array}$ \\
\hline 3. & $\begin{array}{l}\text { Aspek Waktu } \\
\text { Penggunaan }\end{array}$ & $\begin{array}{l}\text { Perangkatnya dapat digunakan dalam jangka panjang dan menjadi } \\
\text { salah satu investasi bagi DANA PENSIUN }\end{array}$ \\
\hline 4. & $\begin{array}{l}\text { Aspek } \\
\text { Aksesbilitas }\end{array}$ & $\begin{array}{l}\text { Dapat terkoneksi dengan SA DKPP yang baru } \\
\text { 5. }\end{array}$ Aspek kedepannya \\
\hline
\end{tabular}

Disamping kelebihan di atas, sistem ini juga memiliki kelemahan antara lain: 
Tabel 3. Kelemahan Sistem Web Application

\begin{tabular}{cll}
\hline No. & Aspek & Keterangan \\
\hline 1. & $\begin{array}{l}\text { Aspek Human } \\
\text { Resources }\end{array}$ & Dibutuhkan orang atau admin didalam penggunaannya \\
\hline 2. & Aspek First Setup & Setup pertama kali cukup membutuhkan effort \\
\hline 3. & Aspek Resources & $\begin{array}{l}\text { Dibutuhkan dana yang cukup besar untuk pertama kali setup, biaya } \\
\text { penyediaan perangkat dan biaya bulanan }\end{array}$ \\
\hline
\end{tabular}

Arsitektur sistem komputer dalam sistem registrasi ulang berbasis Web Application adalah sebagai berikut:

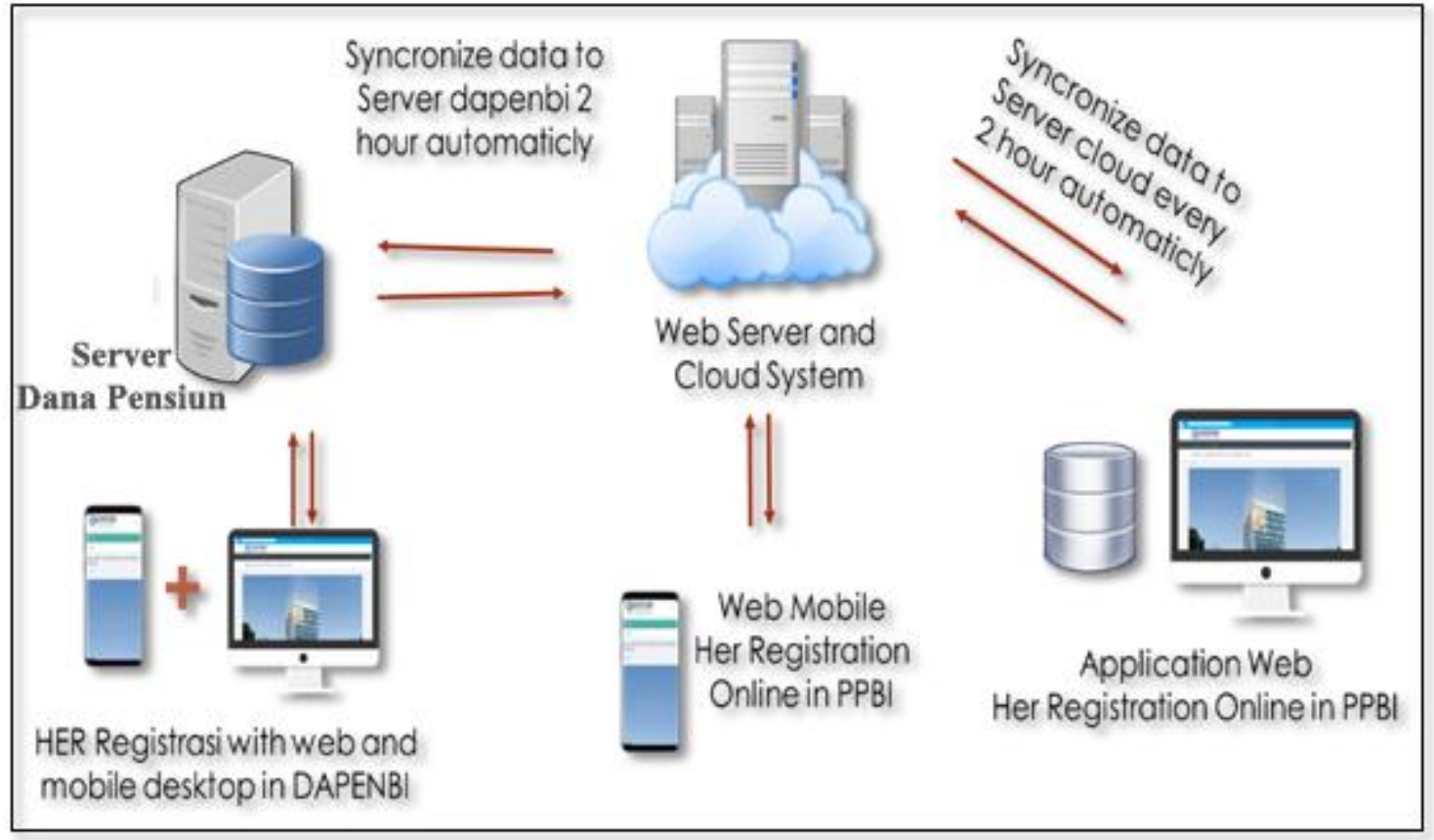

Gambar 4. Arsitektur Registrasi Ulang Berbasis Web Application

Berdasarkan arsitektur sistem tersebut di atas, perangkat untuk registrasi ulang yang berada di Perkumpulan Pensiunan cabang atau kantor DANA PENSIUN terhubung dengan sebuah cloud system. Didalam cloud tersebut tersimpan suatu database yang berisi data administratif Penerima MP yang sifatnya tidak rahasia. Apabila seorang Penerima MP melakukan registrasi ulang, maka sistem menarik data yang bersangkutan dari cloud untuk kemudian di-update oleh Admin. Data yang telah di-update tersebut akan dikirimkan kembali ke dalam cloud. Sinkronisasi data antara Database DANA PENSIUN dengan cloud dilakukan setiap 2 jam sekali.

Sistem Registrasi Ulang dengan Web-Mobile terbagi dalam 2 (dua) tahapan yaiu pendataan awal dan registrasi ulang. Kedua tahapan ini memliki alur proses yang sedikit berbeda yaitu sebagai berikut: 


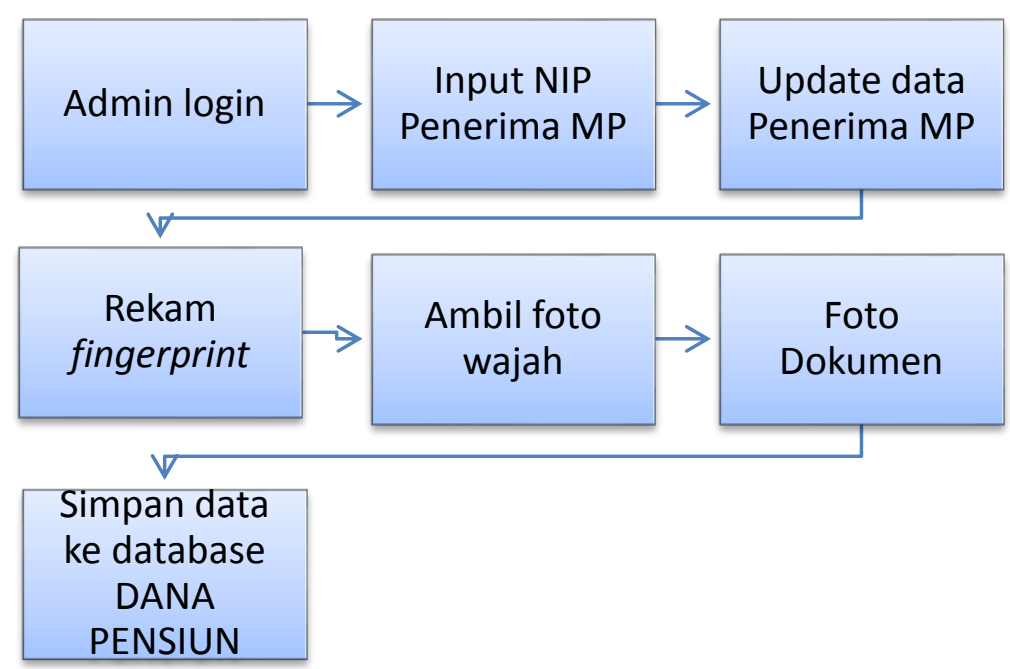

Gambar 5. Proses Bisnis Pendataan Awal (Perekaman Sidik Jari) Dengan Web Application

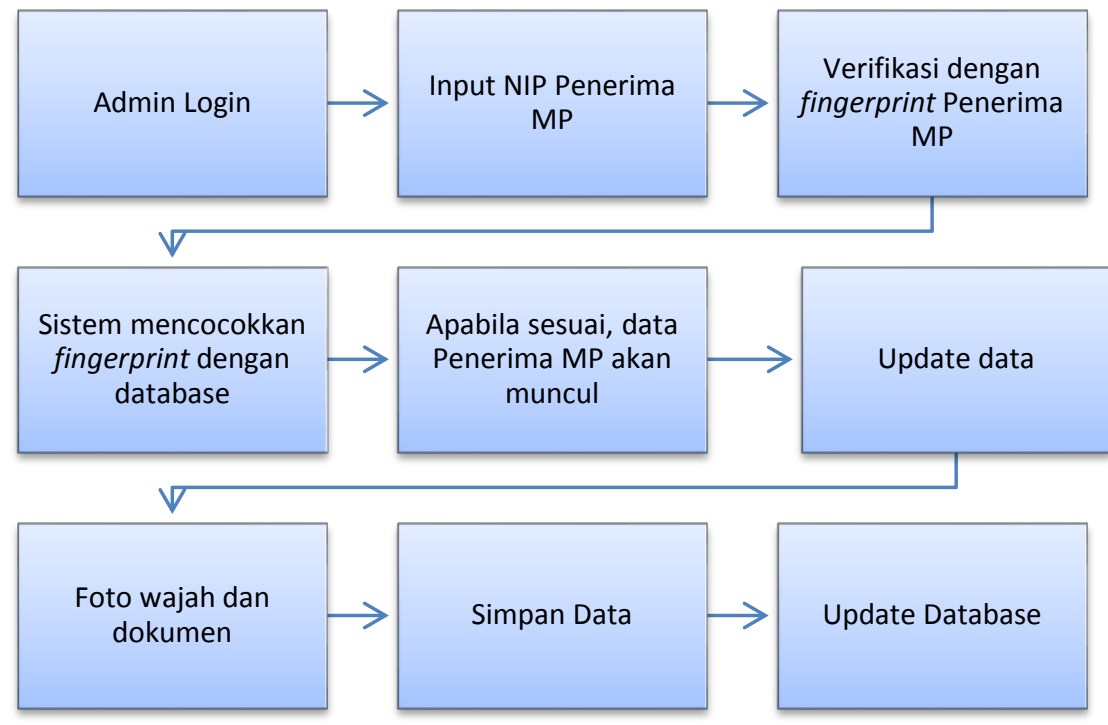

Gambar 6. Proses Bisnis Registrasi Ulang Dengan Web Application

Pada sistem Registrasi Ulang berbasis Web Application terdapat pendelegasian wewenang dari DANA PENSIUN kepada PIC PPBI yang ditunjuk sebagai Admin oleh DANA PENSIUN. Delegasi tersebut berupa kewenangan untuk melakukan login pada sistem aplikasi tersebut, namun untuk dapat melihat dan meng-update data pribadi Penerima MP secara lengkap diperlukan verifikasi fingerprint Penerima MP yang bersangkutan.

\subsection{Registrasi Ulang Online Berbasis Mobile Application}

Registrasi Ulang Online berbasis Mobile-Application merupakan sebuah sistem registrasi ulang hasil pengembangan dari Registrasi Ulang Online berbasis Web-Mobile. Kelebihan utama dari sistem ini adalah tersedianya aplikasi Mobile Android $[12,16]$ yang dapat di-download oleh Penerima MP sehingga Penerima MP dapat melakukan registrasi secara mandiri di smartphone [14] mereka. 
Arsitektur sistem komputer dalam sistem registrasi ulang berbasis mobile-application adalah sebagai berikut:

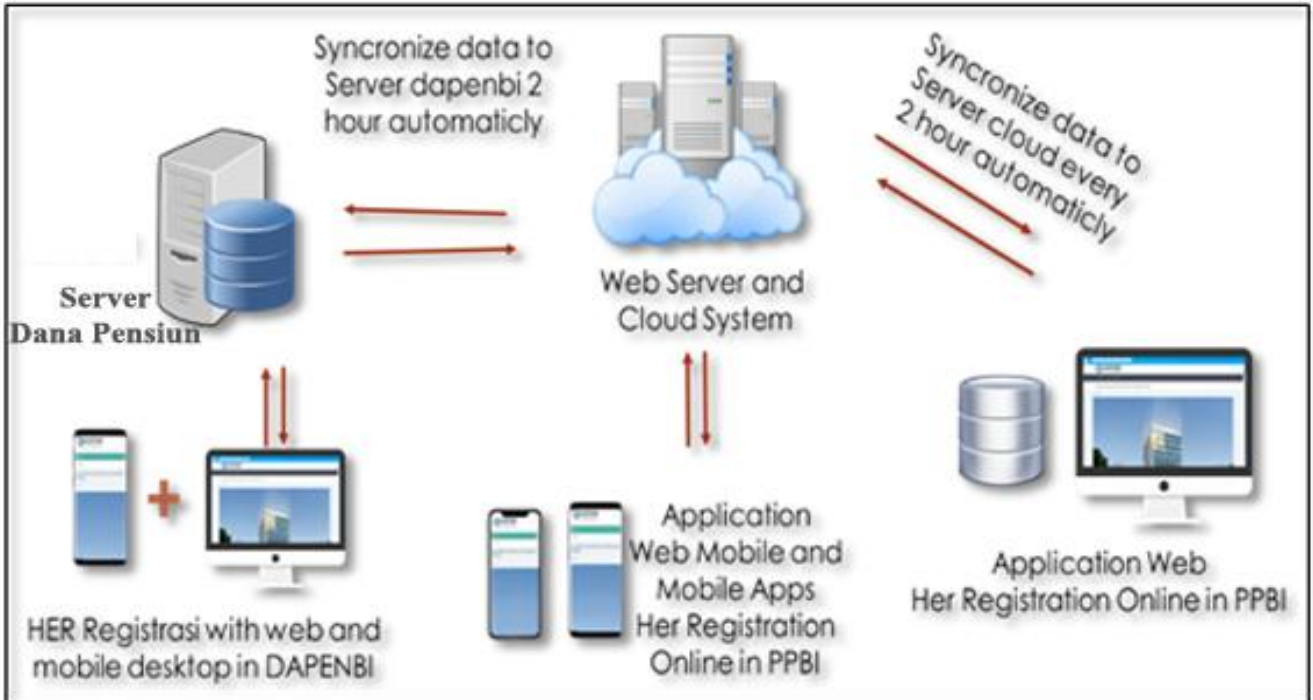

Gambar 7. Arsitektur Registrasi Ulang Berbasis Mobile Application

Berdasarkan arsitektur sistem tersebut di atas, smartphone Penerima MP yang telah men-download aplikasi Registrasi Ulang Online terhubung dengan sebuah cloud system. Didalam cloud tersebut tersimpan suatu database yang berisi data administratif Penerima MP yang sifatnya tidak rahasia. Apabila seorang Penerima MP melakukan registrasi ulang melalui smartphone mereka, maka sistem menarik data yang bersangkutan dari cloud untuk kemudian di-update oleh yang bersangkutan. Data yang telah di-update tersebut akan dikirimkan kembali ke dalam cloud. Sinkronisasi data antara Database DANA PENSIUN dengan cloud dilakukan setiap 2 jam sekali.

Berikut alur proses registrasi ulang dengan mobile-application:

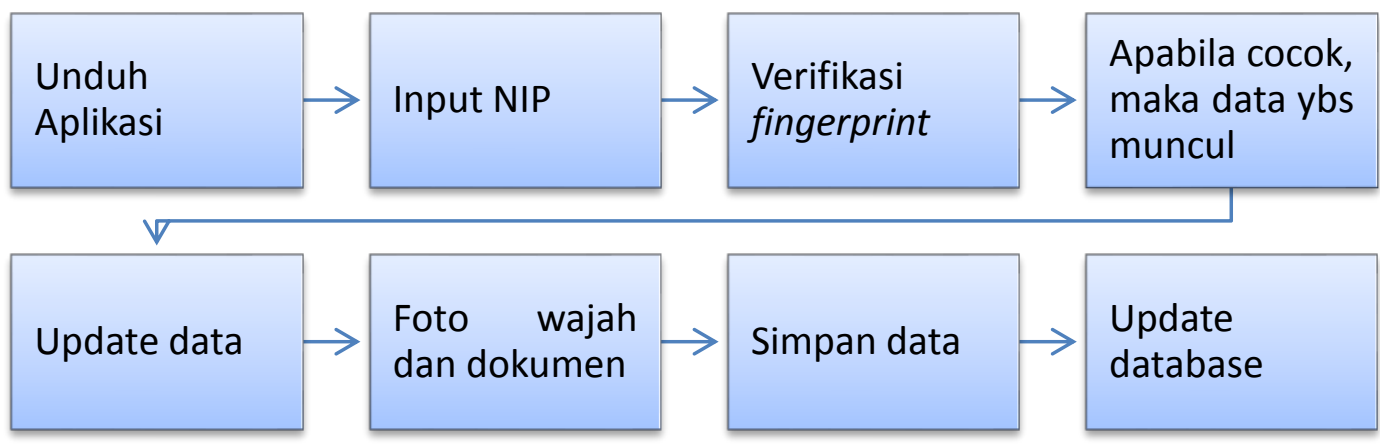

Gambar 8. Proses bisnis Registrasi Ulang dengan Mobile-Application

Registrasi Ulang berbasis mobile-application dapat diakses oleh Penerima MP melalui smartphone mereka dengan mengunduh Aplikasi Registrasi Ulang DANA PENSIUN di Playstore/Appstore. Selanjutnya, mereka dapat melakukan registrasi ulang secara mandiri. Tahapan awal, Penerima MP harus menginput NIP mereka kemudian verifikasi dengan fingerprint. Apabila fingerprint cocok, maka ybs dapat melakukan pengkinian data ybs. Data tersebut antara lain tanggal lahir (berdasarkan dokumen yang sah), tanggal pernikahan kembali, status pernikahan, alamat surat menyurat, nomor telp / HP dan alamat email. Kemudian ybs 
melakukan foto wajah $[15,17]$ dan foto dokumen. Apabila data yang diinput telah sesuai, maka ybs dapat menyimpan data sehingga data tersebut terkirim ke cloud DANA PENSIUN untuk kemudian disinkronisasi ke database DANA PENSIUN tiap 2 jam sekali.

Keunggulan dari sistem registrasi ulang berbasis mobile-application antara lain:

Tabel 4. Keunggulan Sistem Mobile Application

\begin{tabular}{cll}
\hline No. & Aspek & Keterangan \\
\hline 1. & $\begin{array}{l}\text { Aspek } \\
\text { Aksebiliti }\end{array}$ & $\begin{array}{l}\text { Dapat dilakukan dimana saja tidak terbatas tempat dan menggunakan } \\
\text { smartphone berbasis android. }\end{array}$ \\
\hline 2. & $\begin{array}{l}\text { Aspek Human } \\
\text { Resources }\end{array}$ & $\begin{array}{l}\text { Setelah dilakukan validasi oleh admin dari perekaman sidik jari dan } \\
\text { pengambilan foto wajah, tidak dibutuhkan admin atau user dari } \\
\text { DANA PENSIUN untuk pengkinian Registrasi Ulang Online. }\end{array}$ \\
\hline 3. & $\begin{array}{l}\text { Aspek } \\
\text { Resources }\end{array}$ & $\begin{array}{l}\text { Tidak diperlukan perangkat tambahan dalam pengkinian Registrasi } \\
\text { Ulang Online. }\end{array}$ \\
\hline 4. & $\begin{array}{l}\text { Aspek } \\
\text { Keamanan }\end{array}$ & $\begin{array}{l}\text { Pengamanan sistem secara bertahap karena pada proses perekaman } \\
\text { dilakukan oleh Admin kemudian baru dapat dilakukan secara mandiri } \\
\text { oleh Penerima MP di smartphone pribadi mereka }\end{array}$ \\
\hline
\end{tabular}
lain:

Sedangkan kelemahan dari sistem registrasi ulang berbasis mobile-application antara

Tabel 5. Kelemahan Sistem Mobile Application

\begin{tabular}{cll}
\hline No. & Aspek & Keterangan \\
\hline 1. & Aspek Peserta & $\begin{array}{l}\text { Tidak semua Peserta mengerti cara penggunaaan aplikasi dan } \\
\text { atau memiliki Android Phone. }\end{array}$ \\
\hline 2. & $\begin{array}{l}\text { Aspek Human } \\
\text { Resources }\end{array}$ & $\begin{array}{l}\text { Dibutuhkan call center jika ada pertanyaan dari peserta atau } \\
\text { user. }\end{array}$ \\
\hline
\end{tabular}

Sistem ini merupakan sistem yang relatif canggih dan efisien bagi DANA PENSIUN, namun mengingat masih banyak Penerima MP yang belum memiliki smartphone yang mendukung aplikasi ini, maka secara paralel sistem registrasi ulang berbasis web-mobile dan manual tetap perlu dilaksanakan.

Untuk memitigasi kelemahan-kelemahan tersebut, pada tahap pendataan awal, Penerima MP diwajibkan untuk melakukan perekaman sidik jari dan pengambilan foto terbaru dengan menggunakan sistem Web Application sehingga terdapat Admin sebagai validator kebenaran data yang bersangkutan dengan tetap membawa dokumen pendukung berupa formulir isian yang ditandasahkan oleh RT/RW atau PPBI Cabang.

\subsection{Uji Coba}

Dalam tahapan ini, DANA PENSIUN bekerjasama dengan Vendor membuat aplikasi registrasi ulang berbasis web-mobile dan mobile-application. Setelah aplikasi tersebut selesai dibuat, performance aplikasi tersebut akan diuji-coba dengan cara melakukan perekaman data sidik jari dan registrasi ulang kepada minimal 100 orang Pensiunan yang diambil sebagai sampel. Sampel tersebut dapat berasal dari : 1. Pensiunan BI yang masih bekerja di DANA PENSIUN, YKKBI, MPI, FFT dan lainnya. 2. Pengurus PPBI Pusat dan PPBI Cabang Jakarta. 3. Koordinator Wilayah dan Koordinator Rayon PPBI di Jabodetabek ( \pm 50 orang). 4. Pensiunan yang berobat di BIMC maupun Kebon Sirih. 
Pada tahap ini, dilakukan pendataan awal dengan mengupdate data diri yang bersangkutan kemudian merekam fingerprint dan mengambil foto terkini untuk kemudian disimpan ke dalam database DANA PENSIUN.

Selain di wilayah Jabodetabek, Uji Coba juga akan dilakukan di wilayah PPBI Cabang Cirebon untuk menguji performance sistem di daerah diluar Jakarta. Pelaksanaan Uji Coba ini bekerjasama dengan PPBI Cirebon untuk mengadakan pertemuan dengan Penerima MP wilayah Cirebon. Sebelumnya, DANA PENSIUN akan mengirimkan surat undangan pertemuan disertai dengan formulir registrasi ulang untuk dapat diisi oleh Penerima MP Cirebon. Selanjutnya, dalam pertemuan yang akan diadakan, Tim DANA PENSIUN bersama dengan Vendor akan melakukan pendataan awal dengan mengupdate data Penerima MP berdasarkan isian formulir dan perekaman sidik jari juga pengambilan foto untuk disimpan ke dalam database DANA PENSIUN.

Setelah itu, DANA PENSIUN bersama Vendor akan melakukan evaluasi terhadap hasil Uji Coba tersebut untuk kemudian dilakukan penyempurnaan terhadap kelemahan-kelemahan sistem registrasi ulang online yang kemungkinan masih terjadi selama pelaksanaan uji coba sistem registrasi online. Apabila sistem registrasi ulang online telah layak digunakan, maka akan dilanjutkan ke tahapan implementasi.

\subsection{Implementasi}

Pada tahun 2019, akan dilaksanakan registrasi ulang umum yang berlaku bagi Pensiunan Peserta, Janda, Duda dan Anak. DANA PENSIUN menargetkan sistem registrasi ulang online berbasis web-mobile dan mobile-application dapat digunakan pada registrasi tersebut, disamping registrasi ulang manual. Pengimplementasian sistem registrasi ulang online dimulai dari wilayah Jabodetabek dan Cirebon.

Implementasi registrasi ulang online tahun 2019 di wilayah Jabodetabek berupa pendataan awal dapat dilakukan dengan beberapa alternatif usulan, antara lain: a. Bersamaan dengan acara sosialisasi di Kantor Pusat (Jabodetabek), kendala waktunya kurang memungkinkan karena pada umumnya pensiunan sudah merasa lelah mengikuti sosialisasi. b. Bersamaan dengan registrasi ulang di DANA PENSIUN, dengan menyediakan konter pelayanan registrasi ulang online lebih banyak (> 2 konter) agar pelayanan cepat, membutuhkan waktu yang cukup lama, tetapi dapat dilakukan seperti pelaksanaan registrasi ulang saat ini. c. Monitoring dengan kunjungan langsung bagi pensiunan yang belum melakukan registrasi ulang. d. Dokumen pendukung berupa formulir isian dari penerima MP yang ditandasahkan oleh RT/RW atau PPBI Cabang.

\section{KESIMPULAN}

Registrasi Ulang merupakan kegiatan pendaftaran ulang yang bertujuan untuk meyakini Penerima MP masih berhak menerima MP sesuai ketentuan berlaku dan pengkinian data Penerima MP. Selama ini, pelaksanaan Registrasi Ulang masih dilakukan secara manual, sehingga terdapat beberapa kendala yang dihadapi. Kendala dimaksud diantaranya keterbatasan SDM DKPP untuk input data dan scanning.

Berdasarkan hasil survey kepuasan Pensiunan tahun 2017 dan 2018, banyak Pensiunan yang mengusulkan Registrasi Ulang secara online agar lebih memudahkan Pensiunan. Selain itu, di Dana Pensiun lain seperti Dapentel dan Dapen Pertamina juga sudah mulai mengembangkan Registrasi Ulang secara online. Oleh karena itu, DANA PENSIUN menganggap bahwa ada kebutuhan untuk menerapkan Registrasi Ulang secara online.

Dalam kajian ini, terdapat 2 (dua) alternatif sistem Registrasi Ulang secara online yaitu Registrasi Ulang berbasis Web Application dan Mobile-Application. Kedua sistem Registrasi 
Ulang secara online tersebut menggunakan fingerprint dan foto terakhir untuk meyakini bahwa Penerima MP masih hidup.

Registrasi Ulang berbasis web-mobile menggunakan perangkat Laptop dan lainnya yang ditempatkan di tempat-tempat yang ditunjuk oleh DANA PENSIUN, sedangkan perangkat yang digunakan dalam Registrasi Ulang berbasis Mobile-Application adalah smartphone yang dilengkapi fitur pemindai fingerprint.

Dengan memperhatikan pro \& kons, konfigurasi sistem, sarana \& prasarana, kelengkapan Usreq, proses bisnis, kemudahan teknologi yang digunakan, dan ketersediaan perangkat serta adanya kesanggupan dari Konsultan IT untuk membuat sistem aplikasi registrasi online baik registrasi ulang berbasis Web Application dan Mobile-application, dapat disimpulkan bahwa kedua sistem Registrasi Ulang secara online tersebut di atas dinilai layak untuk dapat diimplementasikan di DANA PENSIUN.

Registrasi Ulang secara online baik berbasis Web maupun Mobile Application tetap dilaksanakan secara pararel dengan sistem Registrasi Ulang manual (berdasarkan formulir isian). Hal ini dimaksudkan untuk memberikan pilihan kepada pensiunan untuk melaksanakan kewajiban melalui Registrasi Ulang yang paling sesuai dengan situasi dan kondisi.

\section{SARAN}

Kebutuhan penerapan Registrasi Ulang Online untuk memudahkan Penerima MP, mendorong DANA PENSIUN untuk mulai melakukan pengembangan terhadap 2 (dua) alternatif Registrasi Ulang di atas secara bertahap. Pelaksanaan Registrasi Ulang Online diperkirakan akan mulai diimplementasikan tahun 2019, namun dengan tetap melaksanakan registrasi ulang manual (menggunakan formulir) sehingga terdapat 3 (tiga) alternatif cara Registrasi Ulang yang dapat dilakukan Penerima MP.

Dalam pengembangan sistem aplikasi Registrasi Ulang berbasis Web-Mobile dan Mobile-Application, DANA PENSIUN akan bekerjasama dengan konsultan IT dalam pembuatan sistem aplikasi. Sebelum pembuatan sistem aplikasi, Tim Registrasi Ulang Online yang dibentuk DANA PENSIUN telah menyusun dan mengusulkan: 1. Spesifikasi hardware dan software, terdiri dari: a. Arsitektur sistem komputer dalam sistem registrasi ulang berbasis webmobile dan mobile-application; b. User requirement SA Registrasi Ulang Online; c. Spesifikasi perangkat yang digunakan; d. Perkiraan anggaran biaya. 2. Proses bisnis Registrasi Ulang Online. 3. Proses pengadaan sistem aplikasi dan perangkat registrasi ulang berbasis online dilakukan oleh Satuan Kerja yang membidangi Teknologi Informasi.

\section{UCAPAN TERIMA KASIH}

Puji serta syukur kami sembahkan kepada TUHAN YME atas segala rahmat dan karunia-NYA sehingga riset internal ini berhasil diselesaikan. Tak lupa kami ucapkan terima kasih kepada keluarga kami Fakultas Ilmu Komputer Universitas Mercu Buana, dan khususnya PUSLIT Universitas Mercu Buana yang telah memberikan support dana penelitian. Tema yang dipilih dalam kegiatan riset internal ini "Registrasi Ulang Bagi Penerima Manfaat Pensiun Yang Berbasis Mobile “. Penulis menyadari bahwa laporan ini masih jauh dari sempurna maka dari itu kritik beserta saran yang membangun sangat penulis harapkan untuk menjadi lebih baik. Semoga laporan ini dapat memberikan manfaat bagi pembaca. Terima kasih. No SPK: 025/588/B-SPK/II/2021 


\section{DAFTAR PUSTAKA}

[1]

[2] 1992, "Pert
ri Kerja",

[3] 1992, "Peraturan Pemerintah Nomor 77 Tahun 1992 Tentang Dana Pensiun Lembaga Keuangan",

[4] _ 2016, "Peraturan Otoritas Jasa Keuangan Nomor 13/POJK.05/2016 Tentang Tata Cara Permohonan Pengesahan Pembentukan Dana Pensiun Pemberi Kerja dan Pengesahan Atas Perubahan Peraturan Dana Pensiun Dari Dana Pensiun Pemberi Kerja".

[5] 2017, A. Yani, "Pengaruh E-Business Atas Proses Dalam Organisasi Bisnis", No. 1, 1621.

[6] Sugiyono. 2012, "Metode Penelitian Kuantitatif, Kualitatif, dan R\&D”, Alfabeta, Bandung

[7] Team Penulis. 2020, "Rencana Induk Penelitian UMB 2021-2025", Universitas Mercu Buana.

[8] A. N. Anastasia and I. Handriani. 2018, "Aplikasi Sistem Order Jasa Graphic Designer Berbasis Web Pada PT. Decorner,” J. Ilm. FIFO, Vol. 10, No. 1, p. 87.

[9] M. Irsan, 2015, "Rancang Bangun Aplikasi Mobile Notifikasi Berbasis Android Untuk Mendukung Kinerja Di Instansi Pemerintahan,” J. Penelit. Tek. Inform., Vol. 3, No. 1, pp. 115-120,

[10] E. Yusriyanah and I. Prihandi, "Aplikasi E-Commerce Petshop Berbasis Web Dengan Metode Incremental (Studi Kasus Puri Vet Kembangan), ” J. Sist. Inf. dan E-Bisnis, Vol. 1, No. 3, pp. 67-73, 2019.

[11] R. Rahmadini. 2019, "Konsep dan Aplikasi Dana Pensiun Di PT Bank Syariah Mandiri Kantor Cabang Binjai", Doctoral dissertation, Universitas Islam Negeri Sumatera Utara.

[12] N. Safaat. 2012, "Pemrograman Aplikasi Mobile Smartphone dan Tablet PC Berbasis Android", Informatika, Bandung.

[13] H. Rohman, U. Darussalam, and N. D. Natashia. 2020, "Sistem Presensi Fingerprint Berbasis Smartphone Android, ” J I M P - J. Inform. Merdeka Pasuruan, Vol. 5, No. 1, pp. $1-5$.

[14] D. D. Prasetya. 2013, "Membuat Aplikasi Smartphone Multiplatform", Elex Media Komputindo. 
[15] A. Darmawan. 2019, "Aplikasi Mobile Pengenalan Wajah Secara Real-Time Berbasis Principal Component Analysis, ” Ubiquitous Comput. ITS Appl. J., Vol. 2, No. 1, pp. 5766.

[16] R. G. Radityatama. 2017, "Rancang Bangun Aplikasi Mobile Android Sistem Kehadiran Mahasiswa Melalui Pencocokan Wajah Dengan Menggunakan Library Android Face Recognition with Deep Learning Studi Kasus Jurusan Teknik Informatika ITS", Doctoral dissertation, Institut Teknologi Sepuluh Nopember.

[17] I. K. S. Widiakumara, I. K. G. D. Putra, and K. S. Wibawa. 2017, "Aplikasi Identifikasi Wajah Berbasis Android,” Lontar Komput. J. Ilm. Teknol. Inf., Vol. 8, No. 3, p. 200.

[18] A. Sumarudin, W. Permana, A. Suheryadi, K. Maulana, and N. Ibrahim. 2019, "Penerapan Sistem Absensi Sekolah Menggunakan Fingerprint Terintegrasi Dengan Smartphone Android,” J. Appl. Informatics Comput., Vol. 3, No. 1, pp. 18-22.

[19] F. Subhi and Jamaludin. 2019, "Rancang Bangun Aplikasi Presensi Menggunakan Fingerprint," CKI SPOT, Vol. 12, No. 1. 